\title{
微少量粉体の定量供給装置の開発研究
}

\section{Study on Powder-Supplying Device Using a Piezoelecrtic Disk}

\section{0}

\author{
研究代表者 東北工業大学工学部情報通信工学科 \\ 教 授 高 野 剛 浩 Takehiro Takano
}

共同研究者 東北工業大学工学部情報通信工学科

研究員 田 村 英 樹 Hideki Tamura

(現山形大学工学部電気電子工学科助手)

共同研究者 山形大学工学部電気電子工学科

教授富川義 朗 Yoshiro Tomikawa

A powder-supplying device using the bending vibration mode of a piezoelectric disk with a twostep cylindrical projection at its center is described. The device has simple structure by which powder on the surface of the vibrator flows out the tip of the projection. Two degeneration modes of $\mathrm{B}_{11}$ vibration of the disk were considered.

The structure of the vibrator and the vibration mode by FEM are shown. Two kinds of powder were tested in the study, one is fly-ash $\left(D_{p 50}=15 \mu \mathrm{m}\right)$, the others are several kinds of white fused alumina and their powder-supplying characteristics were measured. The results show that the device can supply the powder composed of its particle size smaller than the size of $10 \mu \mathrm{m}$ at flow rate of less than $1 \mathrm{mg} / \mathrm{s}$.

\section{研究目的}

現在, 医薬品や食料品, 電子部品をはじめとする様々 な分野で粉体が利用されている。この中で粉体成形や 粉末の添加などでは, 成形品の小型化や添加物の高精 度化が近年急速に進んでおり, 高精度な粉体移送, 粉 体供給方法の開発が強く望まれている。

筆者らは超音波伝送体として伝搬損失の多い材料を 用いることにより，終端で吸収素子を用いることなく 伝送体に屈曲進行波が励振できること, さらにこの屈 曲進行波を利用する粉体移送デバイスを提案し, この デバイスが少量の粉体の定量的な移送・供給に有効に 活用できることを報告してきた ${ }^{1), 2)}$ 。しかしながらこ
の方法では, 一般的に粒径が小さい場合には，パイプ への粉体の取り込みや粉体供給の定量性などに問題が あった。

微少量粉体の供給・移送を目的として超音波振動を 利用した報告はいくつか見られる ${ }^{3), 4)}$ 。その一つはラン ジュバン型振動子を用い, 水を介してガラス管を振動 させて粉体を落下供給させる方法であり, 数 $\mu$ 程度の 粒径の粉体まで精度良く供給できることが報告されて いるが，その装置は大きくまた高入力が必要である ${ }^{4} 。$ そこで我々は超音波振動を直接粉体に与え, 落下供給 させる方法に着目した ${ }^{5)}$ 。

本研究では振動子として, その中央部に 2 段の突起 を持つ圧電円板振動子を用いた構成について検討し 
た。円板の非対称な屈曲振動によって, 突起の先端部 に励振される振動によって粉体を振るい落とす構造と なっている。実際には $2 つ の$ 縮退する屈曲モードによ って生じる，先端部の楕円運動を利用することでより 安定な供給ができることを実験的に確かめた ${ }^{6), 77}$ 。粒 径が $10 \mu \mathrm{mm}$ 以下の粉体を $1 \mathrm{mg} / \mathrm{s}$ 程度の流量で安定 に供給できることが確認された。

\section{研究成果の概要}

\section{1. 振動子の構造と振動モード}

振動子はジュラルミン製で Fig.1に示すように，円 板の中心に大小 2 段の円筒状の突起を持ち，周辺は薄 肉部分を介して図のように固定している。振動子の外 径は $40 \mathrm{~mm}$, 外周部分の厚さが約 $3 \mathrm{~mm}$ で, 中心方向 に向かって図のように多少テーパを付けている。駆動 用の圧電セラミックス（厚さ $1 \mathrm{~mm}$, 外径 $40 \mathrm{~mm}$, 内 径 $14 \mathrm{~mm}$ ）は振動子の下部に，直交する 2 つの面垂直

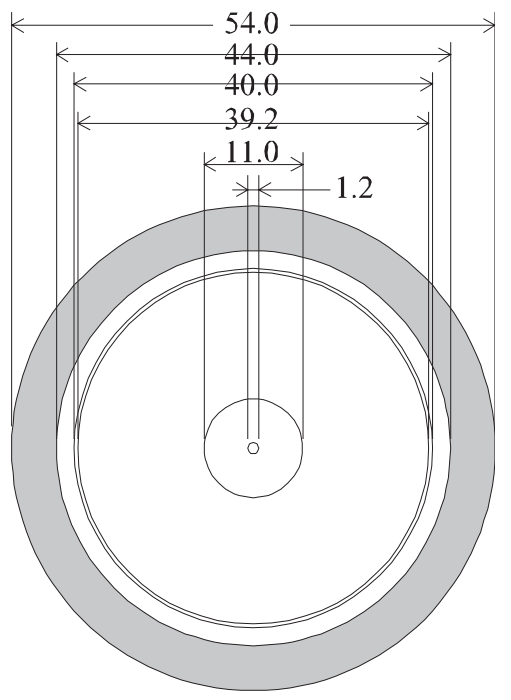

(a) Top view.

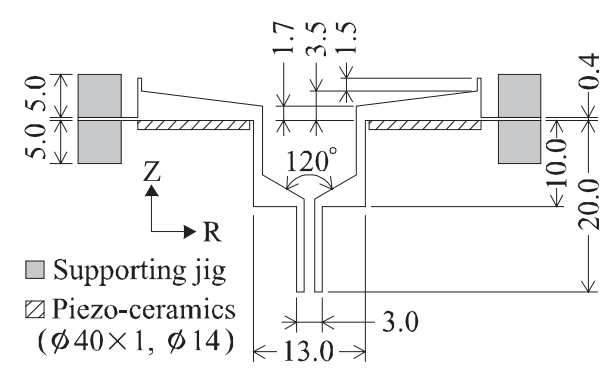

(b) Side view.

Fig.1 Piezoelectric disk with two-step cylindrical projection.
振動 $\mathrm{B}_{11}$ モード（1：節円数， 1 ：節直径数）が励振 できるよう分割分極され接着されている ${ }^{8)}$ 。中段部の 底部にもテーパをつけているが，これは振動子の上部 と同様に振動子の中央部に粉体が集まり易くするため である。実験では中段部突起の寸法の異なる 3 種類の 振動子を用いて，その粉体移送特性を比較検討してい る。Table 1 に使用した振動子の寸法を示している。 ここで，a，bはそれぞれ中段部の内径，外径， c は 細管部の内径，d はセラミックスの内径である。

Table 1 Dimensions of the disk vibrator.

\begin{tabular}{|l|c|c|c|c|}
\hline & $\mathrm{a}[\mathrm{mm}]$ & $\mathrm{b}[\mathrm{mm}]$ & $\mathrm{c}[\mathrm{mm}]$ & $\mathrm{d}[\mathrm{mm}]$ \\
\hline 振動子 1 & 11 & 13 & 1.2 & 14 \\
\hline 振動子 2 & 11 & 13 & 1.5 & 14 \\
\hline
\end{tabular}

Fig.2 に試作した振動子の写真を示している。裏面 の圧電セラミックスは, 図のように 4 分割され対角の 電極を対として $90^{\circ}$ 位相差の入力で駆動される。

円板の面垂直振動 $\mathrm{B}_{11}$ モードには Fig.3に示すよう に直交する 2 つのモードが存在する。これらのモード を $90^{\circ}$ 位相の異なる信号で駆動すると，モード回転 が生じることは良く知られている。実験では，このモ ード回転によって発生する細管部の楕円運動を利用し て，その先端から粉体を落下供給している。この理由 は，単一の共振モードを利用する場合よりも，モード 回転を利用した場合の方が，安定に粉体が供給された からである ${ }^{9)}$ 。なお，振動子 1 での $\mathrm{B}_{11}$ モードの共振 周波数は約 $43 \mathrm{kHz}$ である。

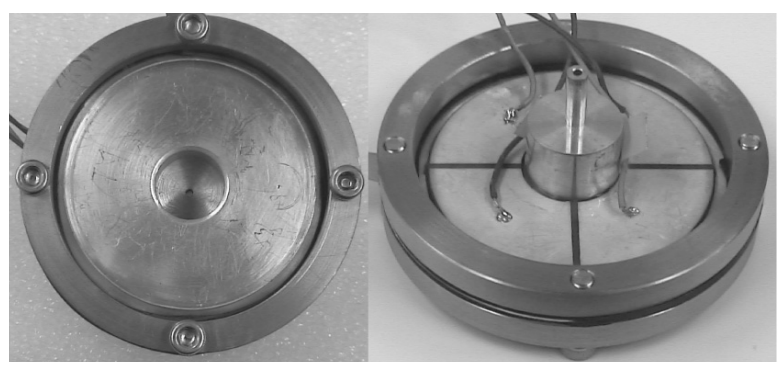

(a) Top view.

(b) Back side view.

Fig.2 Piezoelectric disk vibrator with two step projection.
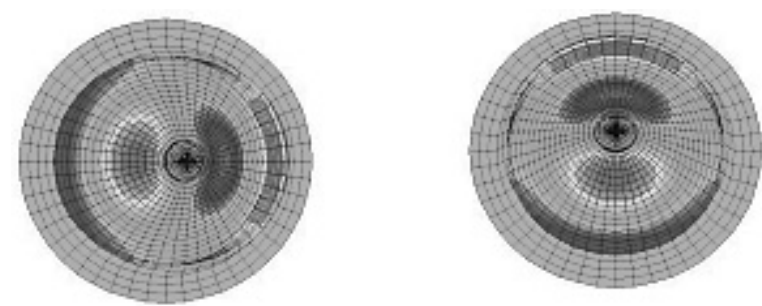

Fig.3 Degeneration modes of $\mathrm{B}_{11}$ vibration mode. 


\section{2. 振動子の有限要素法解析と振動測定}

有限要素法解析プログラム（Piezo Plus）を用いて 振動子 1 の振動解析を行い, 各部の振動の様子を調心 た。Fig.4 (a)，(b) にその結果を示している。同図 (a) は振動子の側面から見たモード図で，(b) は振動子 断面のモード図であり，中段部から細管部内部の動き がよく分かる。

Fig.5に振動子上部より見た，振動子表面の振動乇 ードの測定を示している。測定にはレーザドップラー 振動計を用い, 白黒を強調するために色を反転し，コ ントラストを強調して示している。節円, 節直径が 1 本ずつ観測され, Fig.3に示した FEM 解析の結果と 良く対応している。

Fig.6に振動子突起部の振動測定の測定值を示して いる。測定は回転モードを励振した状態で同図中に示 すように細管部の先端から中段部まで測定した。最終 点は, 両部の境界から約 $3 \mathrm{~mm}$ 中段部に入ったところ である。Fig.6から分かるように細管部は, 先端から

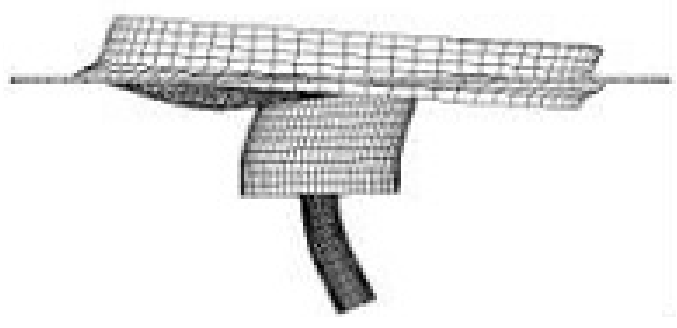

(a) Side view.

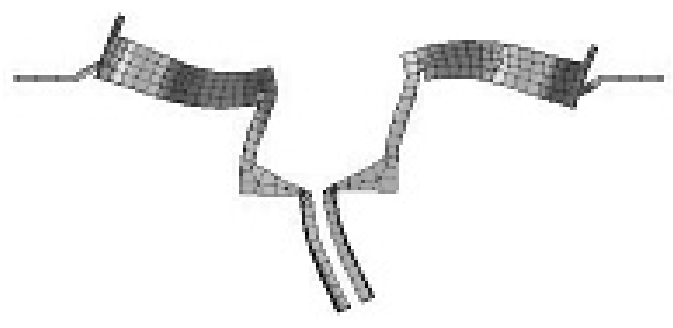

(b) Cross section view.

Fig.4 Vibration mode of the trial vibrator.
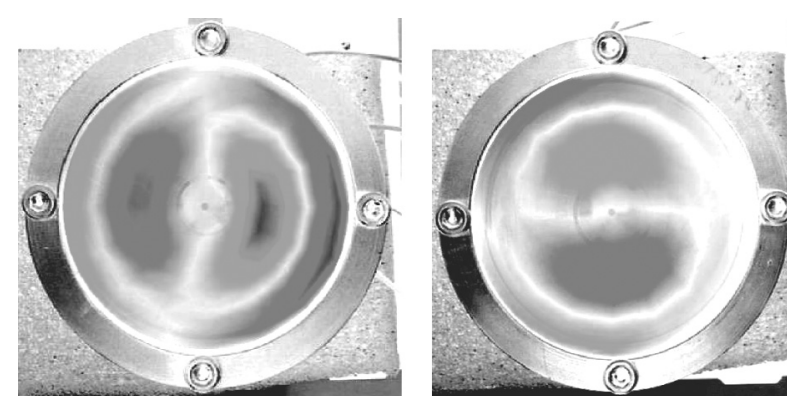

Fig.5 $B_{11}$ vibration modes of the vibrator by LDV.
$4 \mathrm{~mm}$ 付近に節点を持っている。これはFig.7 のレー ザドップラー振動計の測定からも明らかで, 中段部も 含めて粉体供給特性への影響について, 今後検討を加 える予定である。

2 相駆動による細管部先端の楕円運動の軌跡を Fig.8に示した。縦, 横軸とも同じスケールであり, 先端部は円形の運動をしていることがわかる。

\section{3. 粉体供給特性}

回転モードを利用する構成は, 突起部の直線運動を 利用する構成に比べて安定に動作する ${ }^{10)}$ 。Fig.9に細 管部先端から吐出される粉体の写真を示した。このよ

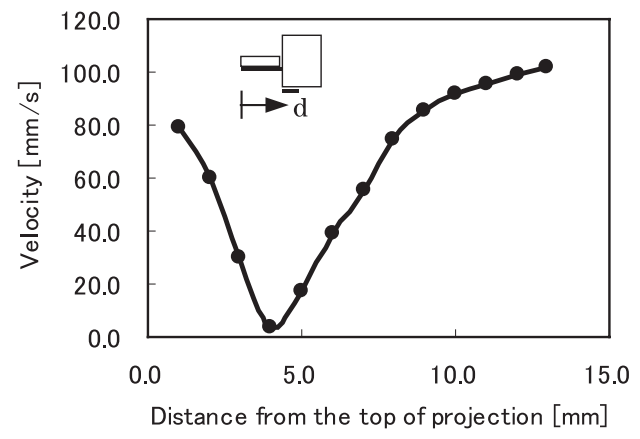

Fig.6 Vibration velocity at the two step projection.

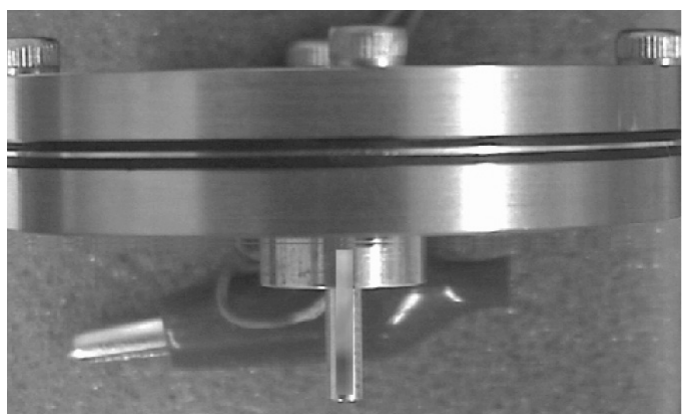

Fig.7 Vibration velocity by LDV at the two step projection.

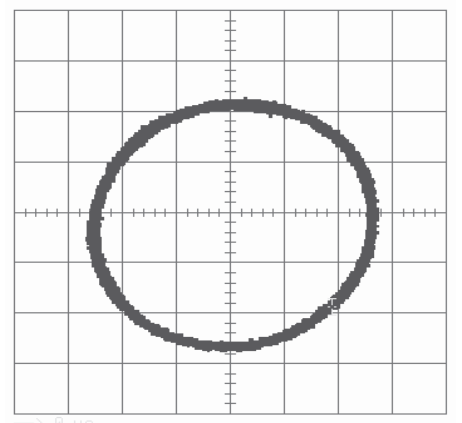

Fig.8 Elliptical motion of vibration velocity of the top of the two step projection. 


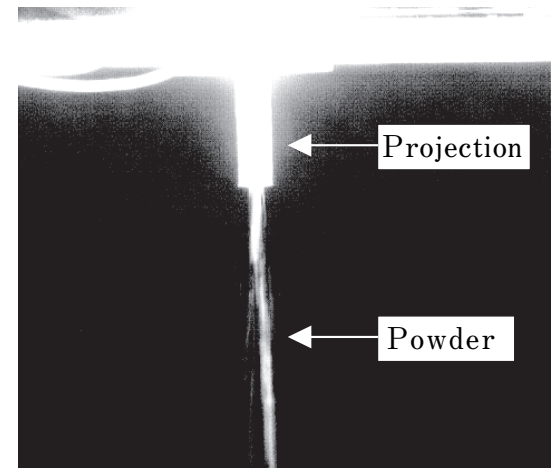

Fig.9 Picture of powder flow from the hole at the tip of projection.

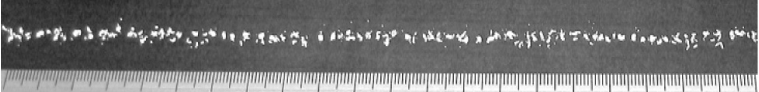

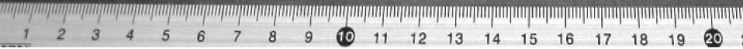

Fig.10 Picture of powder dropped on the moving paper.

うに粉体は連続的に吐出されるが，多少の濃淡も観測 される。Fig.10には吐出した粉体の様子を示している。 これは細管部の下に帯状の紙を敷き，その紙を一定速 度 $(8 \mathrm{~mm} / \mathrm{s})$ で移動して，粉体の吐出の様子を観察 したものである。振動子 1 でアルミナNo.1（平均粒 径 $2 \mu \mathrm{m} ）$ を用いたものであるが，ムラなく安定に吐 出されているのが分かる。

粉体供給特性を Fig.11～Fig.15に示す。Fig.11～ Fig.13の測定は，振動子上に粉体を充填した状態で， 10 ～ 30 秒間入力電力を印加し，供給される粉体の毎 秒当たりの平均重量を求めたものである。いずれの場 合も 3 回の測定をプロットしているが，バラッキは少 なく, $1 \mathrm{mg} / \mathrm{s}$ 前後の微少量粉体の供給が可能である ことを示している。

Figs.11,12 は，細管部の内径がそれぞれ $1.2 \mathrm{~mm}$,

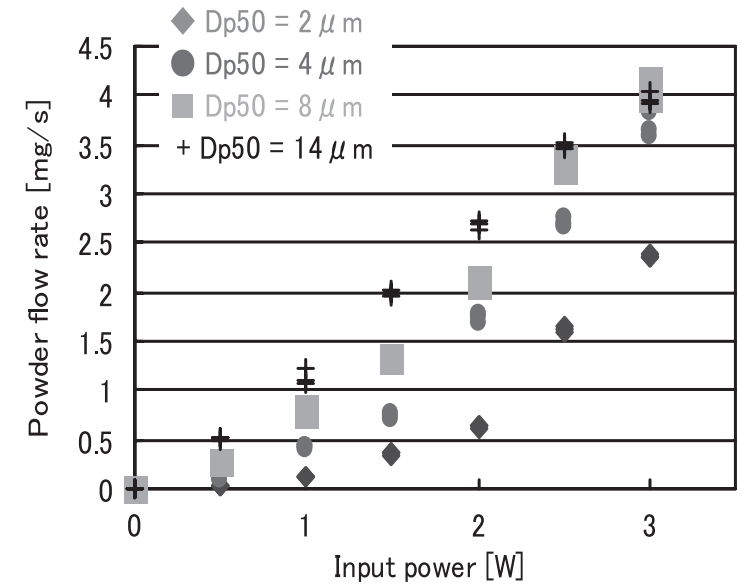

Fig.11 Powder flow rate of the device using the vibrator 1 ( $c=1.2 \mathrm{~mm}$, powder : alumina).
$1.5 \mathrm{~mm}$ の振動子の測定值で，いずれの場合も粒径が 大きくなると，供給量は入力電力に対して直線的に増 加する。また入力電力が大きくなるとバラツキも大き くなるが，これは測定中の動作点の変動が影響を与え ているものと考えている。

細管部の内径 $\mathrm{c}=1.2 \mathrm{~mm}$ の振動子を用いた時のフラ イアッシュの測定值をFig.13に示す。フライアッシ ユの平均粒径は $15 \mu \mathrm{m}$ と大きいが, 流量はアルミナ No.1の $1 / 2$ 程度である。粉体の粒子形状や粒径分布 など様々な要因があると思われるが，この場合はそれ ぞれの粉体の粒子密度の違い（アルミナ：3.9〜 4.0g/ $\mathrm{cm}^{3}$, フライアッシュ : $\left.2.0 \sim 2.3 \mathrm{~g} / \mathrm{cm}^{3}\right)$ が最も影響 を与えているものと考えられる。

Figs.14,15には，供給時間に対する吐出された粉体 の重量を示している。それぞれ入力電圧が $1 \mathrm{~V}, 2 \mathrm{~V}$ の場合であり，1秒間隔で 20 秒間測定し，3 回の測定 值をプロットしている。多少のバラッキはあるが，流 量は入力電圧に対して直線的に増加し，2つのグラフ

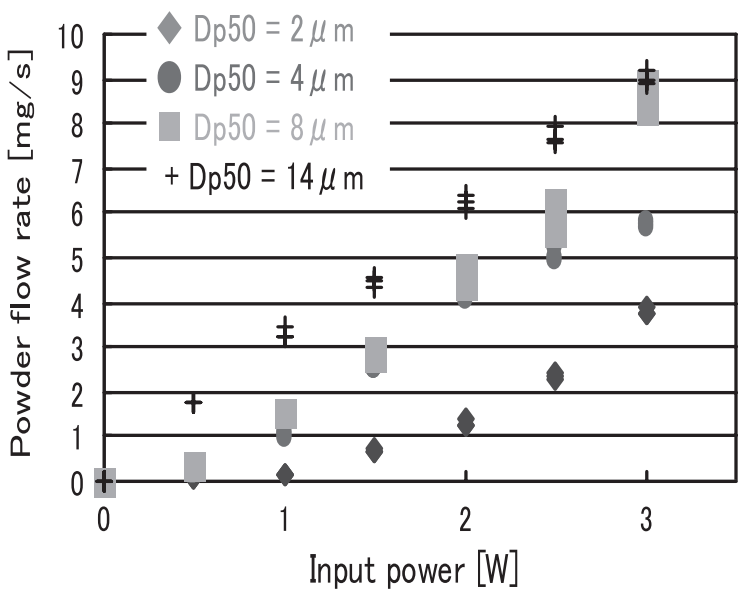

Fig.12 Powder flow rate of the device using the vibrator 2 ( $c=1.5 \mathrm{~mm}$, powder : alumina).

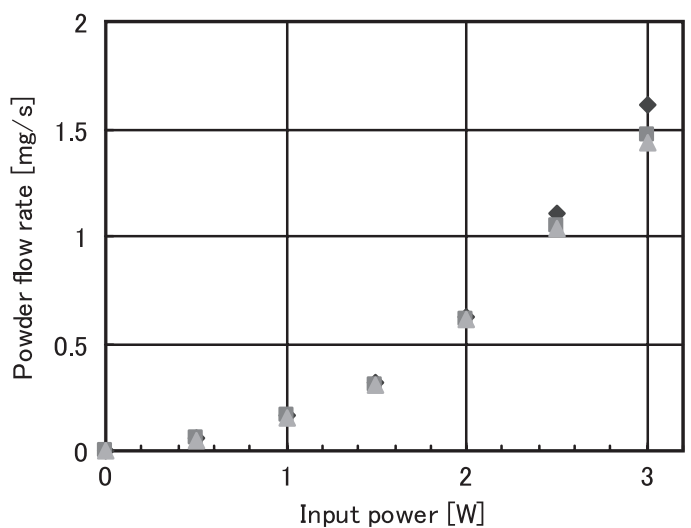

Fig.13 Powder flow rate of the device using the vibrator 1 ( $c=1.2 \mathrm{~mm}$, fly-ash). 


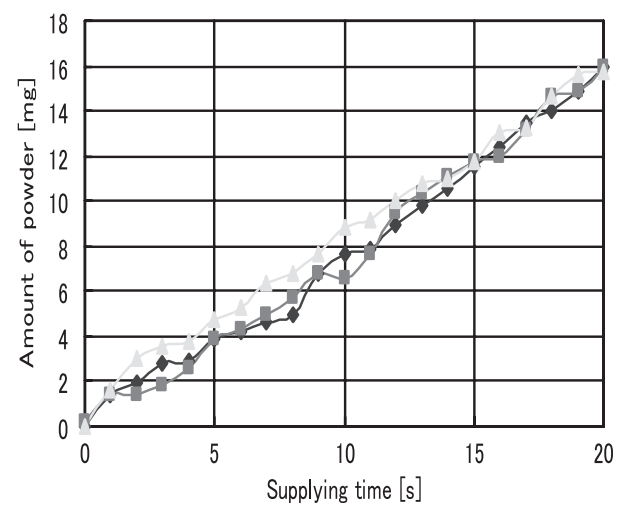

Fig.14 Amount of powder vs supplying time (Input $1 \mathrm{~V}$, powder : alumina No.3).

を比較すると流量差は約 1.6 倍となっている。Fig.15 では, 入力を加えた瞬間の吐出量が多いが, これは細 管部に充填されている粉体が，急激な入力によって纏 まって排出されるためと思われる。

\section{4. まとめ}

中央部に 2 段の突起を持つ圧電円板振動子を用いた 粉体供給デバイスについて報告した。粉体として, JIS の標準粉体である白色溶融アルミナとフライアッ シュを用いて, 粉体の粒径や粉質と供給量の関係につ いて，実験的な検討を加えた。使用した振動子が 2 種 類のみであるが，この方法は粒径が $10 \mu \mathrm{m}$ 以下の粉 体を, $1 \mathrm{mg} / \mathrm{s}$ 程度の微少量粉体の定量供給に有効に 利用できることを明らかにした。振動子形状の影響な ど，今後さらに改善を加えたい。さらに従来提案して いる減衰屈曲進行波を利用する移送デバイスとの組み 合わせによる微少量粉体の定量移送・供給デバイスな ども試みてみたい。

\section{今後の研究の見通し}

中央部に 2 段の突起を持つ圧電円板振動子を用い た, 微少量粉体の定量供給デバイスについて，その構 成と粉体供給特性について検討した。試料として標準 粉体である白色溶融アルミナを用いた場合の供給特性 は, $1 \mathrm{mg} / \mathrm{s}$ 程度の微少量粉体を安定に供給できるこ とが確かめられたが, 振動子形状による影響など今後 さらに検討する必要がある。

より精度高めるためには, 粉体流量センサを開発し, 流量制御を行うことが求められている。今回の研究対 象として駆動・制御まで含めており, 粉体流量センサ

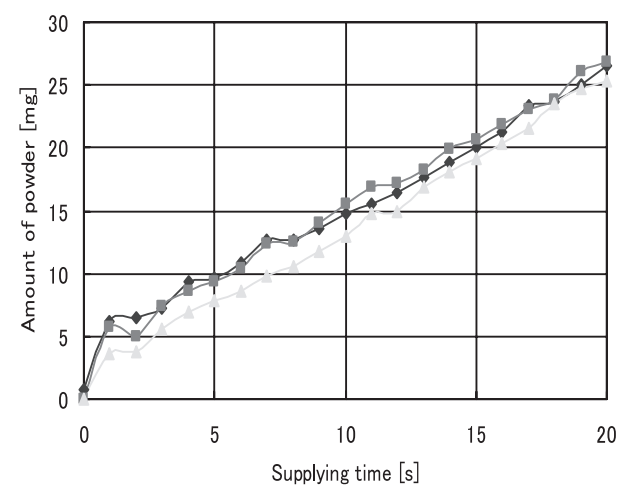

Fig.15 Amount of powder vs supplying time (Input $2 \mathrm{~V}$, powder : alumina No.3).

として振動子への負荷効果の利用などいくつかの方法 を試みたが，感度の良い安定なセンサを実現すること はできなかった。今後に与えられた大きな課題として 残っている。

さらに，駆動系を簡易化するために単相駆動による モード回転を実現し，それによる粉体供給を試みたと ころ，定量性の問題などはあるが粉体供給が可能であ ることを確かめた。制御を考える場合は，単相駆動が 有効なので, 適応性なども含めて検討する予定である。

\section{参考文献}

1 ) T.Takano et al., Jpn.J.Appl.Phys., Vol.30, Suppl.30-1, pp.200-202 (1991).

2 ) T.Takano, Y.Tomikawa, Smart Mater. Structure, Vol.7, No.3, pp.38-42 (1997-6).

3 ) 山田他：日本音響学会誌, 50 巻 5 号, pp.369-373 (1994-05).

4 ) Matsusaka et al., Advance Powder Technology, Vol.6, No.4, pp.283-293 (1995).

5 ）高野, 富川他：日本音学会 2001 春季講論集, pp.909-910 (2001-3).

6 ) 高野, 富川他:VS Tech '03 講演論文集, pp.62-65, (2003).

7 ) T.Takano, Y.Tomikawa et al., Proc. of 2002 IEEE US Symposium, pp.657-660 (2002).

8 ）鈴木他：日本音響学会誌, 58 巻 7 号, pp.398-405, (2002-07).

9 ) 高野, 富川他：日本音学会 2004 春季講論集, pp.879$880(2004-3)$.

\section{本研究助成による学会発表}

1 ) 高野, 田村他：電子情報通信学会超音波研究会技術報 告, US2004-55, pp.43-48 (2004-9).

2 ) 高野, 田村他：日本音学会 2004 秋季講論集, pp.1177-1178 (2004-9). 